\title{
Judicial activism and overreach in India
}

\author{
by R Shunmugasundaram
}

"Courts have played a salutary and corrective role in innumerable instances. They are highly respected by our people for that. At the same time, the dividing line between judicial activism and judicial overreach is a thin one.

Prime Minister Dr Manmohan Singh said the above while addressing a conference of Chief Ministers and Chief Justices of the High Court in April 2007 at New Delhi. This statement is perceived to be the fall out from the widespread debates going on in various forums in India regarding judicial accountability. At the conference of Chief Justices of High Courts and Chief Ministers in the previous year the Prime Minister, Dr Manmohan Singh, said:

"There is growing dissatisfaction regarding the functioning of the executive and the legislature and their ability to deliver effective governance to meet the needs and challenges of our times.

In this background, it is a matter of great satisfaction that the public at large continues to hold our judiciary in high esteem. The judiciary as custodians and watchdogs of the fundamental rights of our people has discharged its responsibility very well indeed."

This article attempts to highlight some of the incidents that would have contributed to the Prime Minister's change of stance. A noted constitutional lawyer and former Solicitor General of India, Mr T R Andhyarjuna, wrote:

$$
\begin{aligned}
& \text {..."whilst the Indian higher judiciary is perhaps the most } \\
& \text { powerful judiciaries in the world today and the socialist } \\
& \text { perception of it is very high, accountability mechanisms } \\
& \text { particularly in the disciplining of judges of superior court and } \\
& \text { the representative character of the courts have not matched } \\
& \text { with the power and esteem" (Judicial Accountability: India's } \\
& \text { Methods and Experience 2003). }
\end{aligned}
$$

\section{JUDICIAL REVIEW}

The Constitution of India provides for judicial review under Articles 32 (Supreme Court) and 226 (High Court). The Supreme Court has pronounced that judicial review is a fundamental feature of the constitution. The power of judicial review by courts therefore is not subject to amendment and thus has been effectively taken out of the field of Parliament's power to amend or in anyway abridge. The judiciary has declared a "hands-off" command to the legislature.
Judicial review is understood to be the revision of the decree or sentence of an inferior court by a superior court. Judicial review of executive or legislative actions is controversial, unlike the judicial review of judicial actions. The orders passed by lower courts which are either being set aside, revised or modified, are greater in number than reviews relating to executive orders or legislative actions. However, criticisms of the judicial review of executive and legislative actions are stronger and more vociferous.

In our constitutional scheme the judiciary alone has been entrusted with the power and duty to test the constitutional validity of legislative provisions and the validity of administrative actions. The superior courts are empowered to declare a statute ultra vires the constitution and to nullify an executive action as unconstitutional. These powers of judicial review are given not with a view to make the judiciary a supreme body superior to the other wings of the constitutional framework, but to ensure a system of checks and balances between the legislature and the executive on one hand, and the judiciary on the other. The mechanism has been devised to function in such a way that the unconstitutional actions of one of the wings are corrected by the other, and vice versa. It is not the purpose of judicial review to criticise legislative or executive actions, as the opposition is expected to fulfil this function in a democratic polity. On the contrary, the judiciary's role is to review executive and legislative actions and declare whether those actions conform with the dictates of the Constitution of India.

Justice Dr A S Anand, former Chief Justice of India and former Chairperson of the Human Rights Commission of India, while addressing on "Judicial review - judicial activism - need for caution" said:

"The legislature, the executive and the judiciary are three coordinate organs of the state. All the three are bound by the Constitution. The ministers representing the executive, the elected candidates as Members of Parliament representing the legislature and the judges of the Supreme Court and the High Courts representing the judiciary have all to take oaths prescribed by the Third Schedule of the Constitution. All of them swear to bear true faith and allegiance to the Constitution. When it is said, therefore, that the judiciary is the guardian of the Constitution, it is not implied that the legislature and the executive are not equally to guard the 
Constitution. For the progress of the nation, however, it is imperative that all the three wings of the state function in complete harmony.

"A judicial decision either 'stigmatises or legitimises' a decision of the legislature or of the executive. In either case the court neither approves nor condemns any legislative policy, nor is it concerned with its wisdom or expediency. Its concern is merely to determine whether the legislation is in conformity with or contrary of the provision of the Constitution It often includes consideration of the rationality of the statute. Similarly, where the court strikes down an executive order, it does so not in a spirit of confrontation or to assert its superiority but in discharge of its constitutional duties and the majesty of the law. In all those cases, the court discharges its duty as a judicial sentinel."

\section{JUDICIAL ACTIVISM}

Courts of today are not remaining passive, with the negative attitude of merely striking down a law or preventing something being done. The new attitude is towards positive affirmative actions, and issuing orders and decrees directing remedial actions.

In the estimation of an ordinary Indian citizen the legislature and the executive have failed miserably in their cherished duties towards the general public. The executive and the legislators are made accountable for their actions. Their nearness to the people generates high expectations from the public and attracts sharp criticism whenever their actions do not follow the expected lines. The common citizen feels that the administration has become so apathetic and non-performing that they have no other option except to approach the judiciary to redress their grievances. It is under this situation that the judiciary has taken an activist approach. Judicial activism has flourished in India and acquired enormous legitimacy with the Indian public. However, this activist approach by the judiciary is bound to create friction and tension with the other organs of the state. Such tension is natural and to some extent desirable.

Judicial activism earned a humane face in India with the liberalising of access to justice and granting of relief to disadvantaged groups and the have-nots through public interest litigation (PIL). A postal letter or even a postcard addressed to the court is accepted for the purpose of initiating prerogative writs, with courts disregarding the technicalities. The Supreme Court of India relaxed the traditional concept of locus by allowing public-spirited citizens to bring public causes to the court. Thus, the number of PIL actions has increased since 1977. The growth of PIL post 1977 is mainly attributed to incidents which happened during emergency rule between 1975 and 1977. One can see the marked differences between the judicial approach prior to 1977 and post emergency rule in India. This change of approach was in response to the changing times and aspirations of the people. Several cases of violations of fundamental human rights were reported during the emergency regime, but still the approach of the courts was conservative.

In ADM Jabalpur v Shukla (1976) 2 SCC 521 the Supreme Court held that a detainee under preventive detention did not have the common law right of securing from the courts his release from an illegal and arbitrary preventive detention order, even if it was passed without the authority of law. The reason given by the court was that the fundamental rights guaranteed under the constitution were suspended during the emergency.

There was a huge change in judicial approach after emergency rule.

\section{THE JUDICIARY IS NOT A DESPOTIC BRANCH OF THE STATE}

Although the Supreme Court of India has widened its scope of interference in public administration and the policy decisions of the government, it is well aware of the limitations within which it should function. In the case of P Ramachandran Rao v State of Karnataka, reported in (2002) 4 SCC 578, has observed that

\footnotetext{
"The Supreme Court does not consider itself to be an imperium in imperio or would function as a despotic branch of the State."
}

The Indian Constitution does not envisage a rigid separation of powers, the respective powers of the three wings being well-defined with the object that each wing must function within the field earmarked by the constitution. The Supreme Court of India took all this into account in the judgment reported in (1986) 4SCC 632 in the case of State of Kerala v A Lakshmi Kutty, stating that

\footnotetext{
"Special responsibility devolves upon the judges to avoid an over activist approach and to ensure that they do not trespass within the spheres earmarked for the other two braches of the State."
}

The judges should not enter the fields constitutionally earmarked for the legislature and the executive. Judges cannot be legislators, as they have neither the mandate of the people nor the practical wisdom to understand the needs of different sections of society. They are forbidden from assuming the role of administrators; governmental machinery cannot be run by judges as that is not the intention of our constitution makers. While interpreting the provisions of the constitution the judiciary often rewrites them without explicitly stating so. As a result of this process some of the personal opinions of the judges crystallize into legal principles and constitutional values.

A classic example of the above problem is the recent order by the Supreme Court of India to demolish and seal off all the commercial entities run in residential areas of Delhi. Even though the Delhi Government passed a Bill regularizing all the constructions, which were illegal, the 
Supreme Court of India took the view that all those places should be sealed off. The Delhi Municipal Corporation was reluctant to continue with the sealing drive because it was against the popular sentiments of the people. However, the Supreme Court remained steadfast in its decision and the municipal authorities had no other option except to go ahead. There were demonstrations and violence against the sealing drive; the Congress Party, which was in power during the sealing drive, lost municipal councillor seats in the elections conducted during that time. The argument over the economic, social and physiological impact the sealing drive would create did not dissuade the court.

The Supreme Court of India is well aware of its limitations, and hence exercises self-restraint and caution over encroachment of the field exclusively reserved for the legislature and the executive. The seven judge bench of the Supreme Court declared in P Ramachandra Rao's case that:

"The primary function of the Judiciary is to interpret the law. It may lay down principles, guidelines and exhibit creativity in the field left open and unoccupied by legislation. But they cannot entrench upon in the field of legislation properly meant for the legislature. It is no difficult to perceive the dividing line between permissible legislation by judicial directives and enacting law - the field exclusively reserved for the legislature."

In the case of Keshavanada Bharathi (1973) the Supreme Court held for the first time that a constitutional amendment duly passed by the legislature was invalid for damaging or destroying its basic structure. This was a gigantic judicial leap unknown to any legal system. The supremacy and permanency of the constitution was ensured by this pronouncement, with the result that the basic features of the constitution are now beyond the reach of Parliament. The criticism of this judgment by the Supreme Court is that since the court has not exhaustively defined what these basic features are, the judicial arm can be extended any distance at will.

Article 21 of the Constitution of India provides that no person shall be deprived of its life and liberty except according to the procedure established by law has become the most dynamic article in the hands of the Indian courts. A whole new set of rights which were not explicitly provided by the constitution were read into Article 21.

\section{SUBSTANTIVE DUE PROCESS AND ARTICLE 21}

The Supreme Court of India gave a new interpretation to Article 21 of the Constitution of India in the case of Maneka Gandhi $v$ Union of India. It became a great trendsetter for further evolution of notions of reasonableness and fairness.

When Maneka Gandhi's passport was impounded, she was served with the required notice under the Indian
Passport Act. She contended that the procedure contemplated under the Act was in violation of the constitution. The Supreme Court held that life does not merely mean an animal-like existence, but an existence with all the freedoms associated with it. The Supreme Court stated for the first that it is not enough merely to prescribe a procedure for denying life and liberty; the procedure itself must be fair and reasonable. This paved the way for the concept of substantive due process, which is not mentioned directly in the Indian Constitution (unlike the American Constitution).

The concept of substantive due process was imported into Article 21 by the decision in Maneka Gandhi. It was asserted by the Supreme Court that the courts have the power to not only judge the fairness and justness of procedure established by a law for the purpose of Article 21, but also the power to judge and decide the reasonableness of the law itself.

\section{LEGISLATION BY THE JUDICIARY}

The Supreme Court of India took serious stance on the sexual harassment of women in the work place. It stated that:

"Each Incident of sexual harassment of woman at workplace results in violation of the fundamental rights of Gender Equality and the Right to Life and Liberty."

In the case of Vishaka v State of Rajasthan, reported in (1997) 6 SCC 241, the Supreme Court lamented that the legislature had not brought in comprehensive legislation to deal with sexual harassment of women in the workplace, and declared the law as follows:

"In view of the above, and in the absence of enacted law to provide for the effective enforcement of the basic human right of gender equality and guarantee against sexual harassment and abuse, more particularly against sexual harassment at work places, guidelines and norms are hereby laid down for strict observance. This is done in exercise of the power available under Article 32 for enforcement of the fundamental rights and it is further emphasised that this would be treated as the law declared by the Supreme Court under Article 141 of the Constitution of India."

This is a clear case of judicial legislation and usurpation of the power of the legislature, but ultimately it benefits the people. When the legislature slumbers, judicial usurpation obtains legitimacy and approval from the general public. There is frequent criticism that, even though 10 years have elapsed since this Supreme Court decision, the legislature has yet to come up with comprehensive legislation dealing with the sexual harassment of women in the workplace.

\section{HISTORY OF JUDICIAL ACTIVISM IN INDIA}

As can be the case in the United States of America and the United Kingdom, ideological confrontation based on the genuine concern for the welfare of the people arose 
between the executive and legislature on the one hand and the judiciary on the other. A conservative executive and a progressive judiciary, or a progressive Parliament and a conservative judiciary coexisting at the same point of time, form the basis of judicial activism or judicial overreach, as opposed to executive excesses or executive enthusiasm beyond the bounds of law.

The evolution of the theory of judicial activism in India can be traced back to the late 1960s or early 1970s during the time when Mrs Indira Gandhi was the Prime Minister of India and an eminent lawyer and legal luminary, Mohan Kumaramangalam, was the Union Minister. When the late Mrs Gandhi attempted to introduce progressive socialistic measures in order to implement her favourite slogan "garibi hatao" (remove poverty) by abolishing Privy Purses and privileges given to the erstwhile rajas and princes of the princely states of pre-independent India, and nationalizing the 14 major banks so as to serve the cause of the poorer sections of the society in a more meaningful manner, a conservative judiciary did not take it kindly and struck down the relevant legislation as unconstitutional. What happened to President Franklin Roosevelt during the period of the great depression and to his new deal legislation happened in India to Mrs Gandhi. The judgment of the Supreme Court of India in the Privy Purse abolition and bank nationalisation cases was considered by Mrs Gandhi to be judicial overreach, and the reaction was at once strong and unequivocal. It is believed that on the advice of Mr Kumaramangalam the conservative and most senior judges of the Supreme Court who participated in the majority judgment in the above cases were passed over for appointment to the post of Chief Justice of India. The dissenting judge, Mr A N Ray, who was fourth in the line of seniority, was appointed, and this resulted in the resignation of the three senior judges (Justices Hegde, Shelat and Grover). This marked the starting point of the theory of judicial activism that actually resulted from the stand-off between the executive and the judiciary.

\section{EARLY CASES OF JUDICIAL ACTIVISM}

The following Supreme Court cases provide a useful insight into the growth and development of judicial activism in independent India.

In the Privy Purse case (Madhav Rao Jivaji Rao Scindiav Union of India, 1970) the broad question was whether the President rightly exercised his power in de-recognising the princes. In this case, the court ruled that by virtue of Article 53 of the constitution, the executive power of union vested in the President must be exercised "in accordance with law". That power was intended to be exercised in aid of, not to destroy, the constitution. An order merely "de-recognizing" a ruler without providing for the continuation of the institution of his rule - an integral part of the constitutional scheme - was therefore plainly illegal.
In $R C$ Cooper $v$ Union of India (1970), the legislative competence of Parliament to enact the Banking Companies (Acquisition and Transfer of Undertakings) Act, known as the Bank Nationalisation Act, was in question. The court struck down the Act primarily on the ground of unreasonableness, explaining that the restriction imposed on the banks to carryon "non-banking business" in effect made it impossible for the banks, in a commercial sense, to carry on any business at all.

In Golaknath v State of Punjab (1971), the Supreme Court while dealing with the constitutional validity of the 17th Amendment to the constitution evolved the concept of "prospective overruling" and held that Parliament had no power to amend Part III of the constitution, or take away, or abridge any of the fundamental rights.

In the fundamental rights case (Keshavananda Bharti v State of Kerala, 1973), the Supreme Court rendered a judgment that can be regarded as an important milestone in the Indian constitutional jurisprudence. While dealing the question as to the extent of the amending power conferred by Article 368 of the constitution, the court evolved the theory of "basic structure." A bench of 13 judges held by a majority of 7:6 that the Parliament had wide powers to amend the constitution extending to all articles of the constitution, but this power could not be used in an unlimited way to abridge, abrogate or destroy the "basic structure" or the "basic framework" of the constitution

In VC Shukla v Delhi Admin (1980), the court while dealing with the legislative competence of the state to pass a law establishing special courts for dealing with offences committed by persons holding high public office, held such courts to be valid. It also held that the court could strike down an administrative act if bias or mala fides was proved. The court in this case clarified that the theory of "basic structure" would apply only to constitutional amendments and not to an ordinary law passed by the Parliament or the state legislature.

In the Bhagalpur Blinding case (Khatri (II) v State of Bihar, 1980), it was held that Article 21 included the right to free legal aid to the poor and the indigent and the right to be represented by a lawyer. It was also held that the right to be produced before a magistrate within 24 hours of arrest must be scrupulously followed.

In Fertilizer Corpn Kamgar Union v Union of India (1981), the petitioners of a public enterprise challenged the sale of the plant and machinery of the undertaking, as it resulted in their retrenchment. The Supreme Court held that sale resulting in retrenchment had not violated their rights under Article 19(1)(g) of the constitution, and likened it to termination of employment due to abolition of posts. The court ruled that the petitioner did not have the locus standi to petition under Article 32. While reiterating that the jurisdiction of the Supreme Court under Article 32 was part of the "basic structure" of the constitution, the court 
held that since the petitioners' fundamental rights were not violated, a petition under Article 32 was not maintainable even though one under Article 226 may be permissible.

In $T V$ Vaitheeswaran $v$ State of TN (1981), the Supreme Court held that a delay in the execution of the death sentence for two years would entitle the prisoner to commutation of the death sentence to one of life imprisonment. However, in Sher Singh v State of Punjab (1983) this view was overruled. In the latter case, the delay was due to the conduct of the convict.

In the judges transfer case ( $S$ P Gupta $v$ Union of India, 1983), the court while dealing with the question of the meaning of the word "consultation" in Article 124(2) held that in the matter of the appointment of judges, the executive is supreme and is not bound by the views expressed by the Chief Justice of India or the other judges of the SC. However, this view has been overruled in S C Advocates-on-Record Association v Union of India in 1993 to ensure judicial supremacy in the appointment of judges.

In the Asian Games case (People's Union for Democratic Rights $v$ Union of India, 1982), the court held that workers temporarily employed by contractors for construction work were entitled to the benefit of the relevant labour and industrial laws and to seek for their implementation under Article 32 of the constitution. The court directed the government and the concerned authorities to ensure compliance with the laws in respect of workers connected with the construction work of the ensuing Asian Games in Delhi.

In A R Antulay v R S Nayak (1984) the court, while dealing with the question of prior sanction for prosecution of a public servant, held that an MLA was not a 'public servant' within the meaning of the relevant clauses as he was not remunerated by the fees paid by the executive in the form of the State Government.

\section{THE PIL REGIME: A HEYDAY OF JUDICIAL ACTIVISM}

The proponents of judicial activism were judges like V R Krishna Iyer, P N Bhagwati, Chinnappa Reddy and D A Desai, who have rendered many judgments touching upon basic rights of the people. It is often said that the genesis of judicial activism lies in the evolution of public interest litigation and the consequent liberalization of the locus standi rule. PIL was originally conceived with the noble objective of empowering the downtrodden, the poor and the needy by ensuring justice to them by relaxing the rigour of locus standi. In 1979 in Hussainara Khatoon v State of Bihar, the Supreme Court first took up a PIL action on behalf of prisoners awaiting trial who had been languishing in jails for periods longer than the maximum punishment prescribed for the offences concerned. The court in this case issued directions ensuring appropriate relief to the prisoners. Thereafter, there was no looking back for PIL; again, in Sunil Batra v Delhi Admin (1980) and in Sheela Barse v Union of India (1983) the court gave significant directions for the protection of accused and convicts (male and female) concerning their safety and security, better conditions in prisons, separate lock-ups for female prisoners, etc.

\section{JUDICIAL ACTIVISM AND ENVIRONMENTAL JURISPRUDENCE}

The steady growth of principles and doctrines that have enriched environmental jurisprudence owe their existence to PIL cases and the accompanying activist approach of the judiciary. In the Oleum gas leak case, the Supreme Court formulated the doctrine of absolute liability for harm caused by hazardous and inherently dangerous industries. It also gave directions which by implication have expanded the jurisdiction of the Supreme Court under Article 32.

Thereafter, right from the rural litigation Kendra case, the court has been propounding principles such as "sustainable development", the "polluter pays" principle, and also adopting certain other principles from international instruments such as the Stockholm Declaration, Rio Declaration, Kyoto Protocol, Biodiversity Convention, the various United Nations Environmental Programmes, etc. In the Narmada Bachao Andolan case, the court has ensured that development by way of building of dams does not take its toll on the employment, shelter and the homes of people. It has directed the State Governments concerned to rehabilitate the displaced people before going ahead. The courts have performed yeomen service to the welfare of the public, especially in the areas of custodial deaths, prisoners' rights, abolition of bonded labour, labourers' rights, fixing absolute liability on hazardous industries, condition of mental homes, regulating pollution, enlarging the scope of "rights to life", etc.

\section{TRESPASSING THE BOUNDARIES: TRANSFORMATION FROM ACTIVISM TO OVERREACH}

In all the above-mentioned cases the judiciary has called upon the executive to perform its obligations under the constitution and the laws. While this was and will continue to be desirable, it will be against the scheme and philosophy of the constitution if the judiciary oversteps and dons the mantle of the executive and the legislature. While in cases related to labour policy (eg minimum wages, working conditions etc) and also in respect of issues related to environmental and ecological matters judicial behaviour can be perceived to be proactive, judicial intervention in matters related to fiscal policy, (political affairs, internal proceedings of the legislature etc) can be categorized as judicial overreach. Frequent interventions tend to weaken the funding of those two wings of the constitution, which are expected to perform by themselves. 
In the words of Justice J S Verma (former Chief Justice of India):

"... the judiciary should only compel performance of duty by the designated authority in case of its inaction or failure, while a takeover by the judiciary of the function allocated to another branch is inappropriate. Judicial activism is appropriate when it is in the domain of legitimate judicial review. It should neither be judicial 'adhocism' nor judicial tyranny."

The acknowledgement of this difference between "judicial activism" and "judicial overreach" is vital for the smooth functioning of a constitutional democracy with the separation of powers as its central characteristic and supremacy of the constitution as the foundation of its edifice.

Glaring instances of judicial overreach include the police reforms case; the sealing of unauthorised commercial operations in Delhi; demolition of unauthorised constructions in the city of Chennai and the creation of a Monitoring Committee to oversee the same; the judgment of the Supreme Court in S R Bommai v Union of India (1994) laying down that the Presidential Proclamation dissolving a State Legislative Assembly is subject to judicial review and that if the court strikes down the proclamation, it has the power to restore the dismissed State Government to office; the Supreme Court's directions to videograph the proceedings of the Jharkhand Assembly and the appointment of a temporary speaker and convening of a special session in the Assembly; declaring as unconstitutional the dissolution of the Bihar Assembly by the Governor thereby diluting the status of the constitutional functionary in Buta Singh's case; creating a central empowered committee (CEC) and giving it powers like that of judicial body; judicial legislation in Vishakha's case regarding the prevention of sexual harassment of women in the workplace; the creation of a high-powered Committee to monitor parking charges; the wearing of helmets; parking space; one-way traffic; black film or vehicle windows; removal of billboards; the usurping of the functions of the TN Public Service Commission by the High Court in the matter of recruitment of District Judges; interference in the educational policies of the Government in examples such as the TMA Pai Foudation case and the Islamic Academy case, to cite a few.

Even the recent Gujarat fake encounter case, in which the court has decided to monitor the investigation and take over the role of the investigating agency while not entrusting the case to the CBI, is a case of over-stepping the constitutional thin line which is the mythological lakshman rekha.

\section{JUDICIAL RESTRAINT: NEED OF THE HOUR}

The Supreme Court has on various occasions highlighted the importance of judicial restraint for the maintenance of the delicate balance of power of the different limbs in a democracy. Justice Markandey Katju in Minor Priyadarshini's case (2005 (3) CTC 449) has explained thus:

"Under the Constitution, the legislature, the executive and the judiciary have their own broad spheres of operation. It is, therefore, important that these three organs of the state do not encroach upon the domain of another and confine themselves to their own, otherwise the delicate balance in the Constitution will be upset... The judiciary must therefore exercise self-restraint and eschew the temptation to act as a super legislature. By exercising restraint, it will only enhance its own respect and prestige... Judicial restraint is consistent with and complementary to the balance of power among the three independent branches of the state. It accomplishes this in two ways. First it not only recognizes the equality of the other two branches with the judiciary, it also fosters that equality by minimizing inter-branch interference by the judiciary... Second, it tends to protect the independence of the judiciary... If judges act like legislators or administrators it follows that judges should be elected like legislators or selected and trained like administrators. The touchstone of an independent judiciary has been its removal from the political and administrative process... Thus, judicial restraint complements the twin, overarching values of the independence of the judiciary and the separation of powers."

In the recent cash for query case (Raja Ram Pal v Hon'ble Speaker, Lok Sabha, 2007) a constitution bench of the Supreme Court has acknowledged the power of the legislature to expel their members, that the legislature is supreme in its own sphere, and it is the sole authority to deal with and regulate its internal proceedings and other affairs.

The Madras High Court has passed the following order in the course of dealing with a PIL case which assailed an executive order regarding the free distribution of colour television sets to eligible families in Tamil Nadu State.

"The scheme is with the proven object of uplift of the poor, needy and under privileged to render social justice, to make them aware of the worldly happenings. A free hand should be given to the Government in spending public money for such purposes. Courts cannot poke their nose into each and every activity of the Government, particularly in the economic activities of the Government, under the garb of judicial review (The Hindu, June 26, 2007)."

\section{LACK OF ACCOUNTABILITY}

The adoption of such an all powerful attitude by the judiciary does not augur well for a healthy democracy. This is underscored by the fact that judiciary as an institution is not accountable to the people in the same way as the legislature and the executive. The actions of the executive are subject to judicial review when there is social, economic or political injustice - or departure from the provisions of law and the constitution. When the legislature makes laws beyond constitutional bounds or 
acts arbitrarily contrary to its basic structure, the highest court examines and corrects. When the judiciary is guilty of excesses, only a larger Bench or a constitutional amendment can intervene. Even today, the only mode of removal of judges as prescribed in the constitution is impeachment, which is too Herculean a task to be easily undertaken. This lack of accountability requires the judiciary to watch its step and exercise self-restraint. Not long ago, a judicial statesman (the late Chief Justice Ismail Mohamed of South Africa) said:

"The independence of judiciary and the legitimacy of its claim to credibility and esteem must in the last instance rest on the integrity and the judicial temper of the judges, the intellectual and emotional equipment they bring to bear upon the process of adjudication, the personal qualities of character they project, and the parameters they seek to identify on the exercise of judicial power. Judicial power is potentially no more immune from vulnerability to abuse than legislative or executive power but the difference is this: the abuse of legislative or executive power can be policed by an independent judiciary but there is no effective constitutional mechanism to police the abuse of judicial power. It is therefore crucial for all judges to remain vigilantly alive to the truth that the potentially awesome breath of judicial POWER is matched by the real depth of judicial RESPONSIBILITY. Judicial responsibility becomes all the more onerous upon judges constitutionally protected in a state of jurisprudential solitude where there is no constitutional referee to review their own wrongs."

\section{ABUSE OF POWER OF CONTEMPT}

The use of the power of contempt by the higher courts has often been uncalled for and unregulated. There are more instances of abuse of the contempt power than its use. Veteran journalist Kuldip Nayar states that "the unpalatable truth is that the judiciary, for some years, has been struck with its own image of authority and truth."
The governance of our Republic, in the totality of administration, is vested in the trinity of executive, legislature, and the judiciary. In a democratic Republic like India the constitution is supreme, and the rule of law requires that every organ of the state, adhere to constitutional policy.

\section{WHAT IS THE SOLUTION?}

A former Solicitor General of India, Mr Dipankar P Gupta, wrote (Hindustan Times, June 15, 2007):

"There is a real danger that the activism of the courts may aggravate the activism of the authorities. Today, inconvenient decisions are left by the executive for the courts to take. Extensive use of judicial powers in the administrative filed may well, in the long-run, blunt the judicial powers themselves. This is not a healthy situation.

"What then is the solution? The task of the court should be to compel the authorities to act and to pass appropriate executive orders rather than substitute judicial orders for administrative ones. They must be told how their duties are to be properly discharged and then commanded to do so. For this, they must be held accountable to the court."

The Supreme Court recently noted in Indian Drugs \& Pharmaceuticals Ltd v Workmen (2007) 1 SCC 408 that: "the Supreme Court cannot arrogate to itself the powers of the executive or legislature... There is a broad separation of powers under the Constitution of India, and the judiciary, too, must know its limits"

- This article is taken from a lecture given at the Institute of Advanced Legal Studies on July 4, 2007.

\section{R Shunmugasundaram}

Senior Advocate, Member of Parliament (Rajyasabha) 